\title{
APPLICATION OF TOLERANCE VALUES AND SOCIAL AT'TITUDES IN SOCIETIES OF DIFFERENT RELIGION IN DUSUN BONDALEM DESA JUMO KECAMATAN JUMO TEMANGGUNG DISTRICT
}

\author{
Elok Ivada Maisara \\ Program Studi Pendidikan Agama Islam IAIN Salatiga, Indonesia \\ E-mail:elokivada03@gmail.com
}

\begin{abstract}
The purpose of this study was to determine the application of the values of tolerance for people of different religions, the application of social attitudes to people of different religions as well as the driving and inhibiting factors for the application of the values of tolerance and social attitudes of interfaith communities in Dusun Bondalem, Jumo Village, Jumo District. Temanggung Regency. This study uses a qualitative research approach because the data and research results obtained are processed and explained based on the author's description. Sources of data in the study include primary data sources, namely the results of interviews, and secondary data sources which can be photos of activities in the community. The results showed that the application of the values of tolerance and social attitudes of the people of different religions in Bondalem Hamlet was the presence of every activity of the people of the Bondalem Hamlet community, all residents participated regardless of their religious background. This is manifested in the daily attitudes of residents in Bondalem Hamlet. The social attitudes that exist in the people of Bondalem Hamlet are very good and are well implemented by the residents of Bondalem Hamlet. The driving factor: all residents want a safe, peaceful and prosperous life, so that in this Bondalem Hamlet, all residents mingle to create such community life. The inhibiting factors for community members in Bondalem Hamlet are economic problems that are generally middle to lower, as well as social problems where residents are fanatical about their religion and problems arise.
\end{abstract}

Keywords: Tolerance Values and Social Attitudes; Communities of Different Religions

\section{PENERAPAN NILAI-NILAI TOLERANSI DAN SIKAP SOSIAL PADA MASYARAKAT BEDA AGAMADI DUSUN BONDALEM DESA JUMO KECAMATAN JUMO KABUPATEN TEMANGGUNG}

\begin{abstract}
Abstrak
Tujuan penelitian ini adalah untuk mengetahui penerapan nilai-nilai toleransi masyarakat beda agama, penerapan sikap sosial pada masyarakat beda agama serta faktor yang mendorong dan faktor penghambat penerapan nilai-nilai toleransi dan sikap sosial masyarakat beda agama di Dusun Bondalem, Desa Jumo, Kecamatan Jumo, Kabupaten Temanggung. Penelitian ini menggunakan jenis pendekatan penelitian kualitatif karena data dan hasil penelitian diperoleh diolah dan dijelaskan berdasarkan deskripsi penulis. Sumber data dalam penelitian meliputi sumber data primer yakni hasil wawancara, dan sumber data sekunder yang dapat berupa foto-foto kegiatan yang ada di dalam masyarakat. Hasil penelitian menunjukkan bahwa penerapan nilai-nilai toleransi dan sikap sosial masyarakat beda agama di Dusun Bondalem adanya setiap kegiatan warga masyarakat Dusun Bondalem semua warga ikut serta tanpa membedakan latar belakang agamanya. Terwujud dalam sikap keseharian warga di Dusun Bondalem. Sikap sosial yang terjalin di masyarakat
\end{abstract}


Dusun Bondalem sangat baik dan diterapkan dengan baik oleh warga masyarakat di Dusun Bondalem. Faktor pendorong: semua warga menginginkan kehidupan yang aman, tentram dan sejahtera, sehingga di Dusun Bondalem ini semua warganya berbaur untuk mewujudkan kehidupan masyarakat yang demikian. Faktor penghambat warga masyarakat di Dusun Bondalem adalah masalah ekonomi yang rata-rata menegah ke bawah, serta masalah sosial adanya warga yang fanatik terhadap agamanya dan timbul masalah.

Kata Kunci: Nilai-Nilai Toleransi dan Sikap Sosial; Masyarakat Beda Agama

\section{PENDAHULUAN}

Berbagai macam agama dan keanekaragaman budaya serta bahasa yang menjadikan Indonesia Negara yang kaya akan kebudayaan. Dalam kehidupan yang beragam agama perlu adanya sikap saling toleransi sesama warga Indonesia. Kemajemukan bangsa Indonesia tidak hanya terlibat dari berbagai jenis suku bangsa, namun juga dari beragamnya agama yang dianut penduduk. Suasana kehidupan beragama yang harmonis di lingkungan masyarakat heterogen dengan berbagai latar belakang agama terbangun karena toleransi masyarakat yang saling menghargai adanya perbedaan. Berbagai kegiatan sosial budaya dalam suatu masyarakat seperti kegiatan gotong-royong dilakukan bersama-sama oleh semua anggota masyarakat tanpa melihat golongan, suku bangsa, dan agama.

Keragaman (pluralitas) adalah sebuah kenyataan hidup di mana setiap orang harus berusaha sampai kepada sikap saling memahami satu sama lain. Dasar keragaman agama adalah kesatuan tujuan dan dialog yang terbuka. Kesadaran terhadap keragaman agama akan melahirkan kesadaran terhadap adanya kesatuan iman. Kesatuan iman bekerja dan menjaga keberlangsungan sejarah wahyu Tuhan, yang dimulai sejak Adam As. sampai dengan Muhammad SAW (Abdussami, 2003: 104).

Di Indonesia agama yang berkembang di dalam masyarakat antaranya agama Islam, Kristen, Katolik, Hindu, Budha, Konghuchu. Dengan adanya berbagai beragaman agama seperti ini, akan muncul banyak konflik baik skala kecil maupun skala besar (Rahmat, 2003: 1) Karena pentingnya rasa saling menghormati dan menghargai antar sesama manusia tersebut maka sikap toleransi harus dibina dengan baik agar keharmonisan dalam masyarakat dapat terwujud. Toleransi adalah kemampuan untuk menghormati sifat dasar, keyakinan, dan perilaku yang dimiliki oleh orang lain. Dalam literatur agama Islam, toleransi disebut dengan tasamuh yang dipahami sebagai sifat atau sikap saling menghargai, membiarkan, atau membolehkan pendirian (pandangan) orang lain yang bertentangan dengan pandangan kita (Naim, 2008: 126).

Toleransi dalam pergaulan hidup antar umat beragama berpangkal dari penghayatan ajaran agama masing-masing. Demi memelihara kerukunan beragama sikap toleransi harus dikembangkan untuk menghindari konflik. Biasanya konflik antar umat beragama disebabkan oleh sikap merasa paling benar (truth claim) dengan cara mengeliminasi kebenaran dari orang lain (Abdussami, 2003: 116).

Agama seringkali menjadi titik singgung paling sensitif dalam pergaulan masyarakat yang plural. Masing-masing pihak mengklaim bahwa dirinyalah yang paling benar, sedangkan pihak lain adalah yang salah. Persepsi bahwa perbedaan adalah merupakan sesuatu yang buruk, suatu hal yang menakutkan, sudah begitu rupa mendarah daging dalam jiwa umat beragama (etnosentrisme). Hal yang sering terjadi adalah bahwa setiap kelompok cenderung menganggap kelompoknya berhak atas klaim kebenaran absolut. Paradigma "orang kita-orang asing" merupakan satu hal yang sering muncul ke permukaan. Implikasi lebih lanjut dari paradigma berpikir yang seperti ini adalah munculnya sejumlah pelabelan-pelabelan terhadap kelompok yang mengarah pada 
pembentukan stereotip yang cenderung negatif. Akibatnya muncul prasangka, rendahnya toleransi dan diskriminasi.

Berkaitan dengan ini, Miswari, (2007: 158) menyatakan toleransi merupakan fundamen dan esensi Islam. Seluruh umat manusia, terutama umat islam menghendaki agar pihaknya menjadi kelompok yang dicintai Tuhan. Maka, Tuhan secara cepat memberikan jawaban agar toleransi dijadikan sebagai bagian utama dalam keberagamaan. Secara genealogis, yang dimaksud dengan agama kehanifahan adalah agama yang dibawa oleh Nabi Ibrahim a.s. sebagaimana dalam Al.Qur'an disebutkan, bahwa agama yang dibawa Nabi Ibrahim merupakan agama yang lurus, toleran dan berserah diri kepada Tuhan secara total (hanifan musliman) (Q.S: Ali Imran [3], 67). Jadi, agama yang mempunyai mandat dari Tuhan adalah agama yang mempunyai dua unsur penting, yaitu keberatan dan toleransi. Karena itu, bila dikaitkan antara ayat tersebut dengan hadis di atas, maka akan ditemukan genealogi dari apa yang disampaikan Nabi perihal ajaran kehanifahan yang toleran, yaitu ajaran yang dibawa Nabi Ibrahim a.s.

Anangguru, (2009: 57) menyatakan bahwa sikap toleran Sang Budha terhadap agama lain diceritakan dalam riwayat percakapan beliau dengan Upali, seorang penganut aliran Jaina, tentang hukum karma. Setelah berdiskusi panjang lebar, Upali meminta agar ia (Upali) dapat diterima oleh sang Budha sebagai muridnya. Sampai tiga kali Sang Budha menolak permintaan itu. Akhirnya Budha menerima Upali sebagai penganutnya, namun mengatakan: "Kami menerima anda sebagai umatku, sebagai muridku. Dengan harapan anda tetap menghargai agamamu dan menghormati batas gurumu itu serta membantunya."

Keragaman pada masyarakat Indonesia, bisa kita temukan dalam kehidupan sehari-hari bahkan hal tersebut seringkali saling berdampingan. Sebagai contoh adalah masyarakat yang dimana dalam lingkup satu lingkungan terdapat dua agama yang mereka anut yaitu agama Islam dan agama Budha. Dengan adanya perbedaan keyakinan dalam satu lingkungan tetapi saling menjaga kerukunan antar umat beragama sehingga terjalin hubungan baik antar masyarakat di lingkungan tersebut.

Sikap sosial masyarakat beda agama saling memahami satu dengan yang lain, dan menghormati serta menghargai sesama masyarakat, yang terjalin di masyarakat kebanyakan di Indonesia dengan mencerminkan kehidupan yang sejahtera saling menghormati dan tolong menolong dengan sesama. Seperti halnya yang terjadi di Dusun Bondalem Desa Jumo Kecamatan Jumo Kabupaten Temanggung yang terdiri dari berbagai macam agama, budaya, dan adat istiadat. Masyarakat yang ada di dusun tersebut beragama Islam dan sebagian beragama Budha. Hubungan masyarakat di dusun tersebut tetap harmonis dan menjaga toleransi antar sesama masyarakat.

Berdasarkan realita yang terjadi di Dusun Bondalem Desa Jumo Kecamatan Jumo Kabupaten Temanggung yang masyarakatnya plural yang terdiri dari agama Islam dan agama Budha, bahkan dalam satu lingkungan memiliki agama yang beragam yang hidup membaur satu sama lain tanpa adannya diskriminasi, penulis tertarik untuk mencari tahu secara mendalam dengan melakukan penelitian, yang berjudul "Penerapan Nilai-Nilai Toleransi dan Sikap Sosial Pada Masyarakat Beda Agama di Desa Bondalem Kecamatan Jumo Kabupaten temanggung" untuk menunjukkkan bahwa nilai- nilai dasar yang menjadi landasan terbentuknya toleransi antar umat beragama secara normatif terdapat pada nilai agama dan nilai budaya.

Fokus penelitian dalam penelitian ini adalah (1) Bagaimanakah penerapan nilai-nilai toleransi pada masyarakat beda agama di Dusun Bondalem Desa Jumo Kecamatan Jumo Kabupaten Temanggung? (2) Bagaimanakah sikap sosial masyarakat beda agama yang 
terjalin di masyarakat Dusun Bondalem desa Jumo Kecamatan Jumo Kabupaten Temanggung?, dan (3) Apa sajakah faktor-faktor yang mendukung dan menghambat penerapan nilai-nilai toleransi dan sikap sosial masyarakat beda agama di Dusun Bondalem Desa Jumo Kecamatan Jumo Kabupaten Temanggung?

\section{METODE}

Penelitian ini menggunakan jenis penelitian kualitatif dengan pendekatan deskriptif. Lokasi penelitian ini dilaksanakan di Dusun Bondalem RT 04 RW 03 Desa Jumo Kecamatan Jumo Kabupaten Temanggung. Pada bulan Juli-Agustus 2020. Subjek penelitian ini adalah masyarakat di Dusun Bondalem yang berbeda agama. Adapun prosedur pengumpulan data yang digunakan dalam penelitian ini, yaitu:

1. Observasi

Observasi adalah kegiatan pengamatan (pengambilan data) untuk memotret seberapa jauh efek tindakan telah mencapai sasaran (Arikunto, 2008: 127). Dengan observasi, peneliti dapat mendokumentasikan dan merefleksi secara sistematis terhadap kegiatan dan interaksi subjek peneliti (Basrowi, 2008: 93). Observasi yang dilakukan peneliti yaitu dengan mengamati bagaimana sikap sosial masyarakat dan sikap toleransi di Dusun Bondalem Desa Jumo Kecamatan Jumo Kabupaten Temanggung, kemudian mendokumentasikan kegiatan di masyarakat untuk memperoleh data yang dibutuhkan dalam penelitian.

2. Wawancara

Wawancara diartikan sebagai percakapan dengan maksud tertentu. Percakapan itu dilakukan oleh dua pihak, yaitu pewawancara (interviewer yang mengajukan pertanyaan dan terwawancara (interviewee) yang memberikan jawaban atas pertanyaan itu (Moleong, 2008: 186). Wawancara yang digunakan dalam penelitian ini adalah wawancara mendalam, suatu kegiatan yang dilakukan untuk mendapatkan informasi secara langsung dengan mengajukan pertanyaan kepada narasumber (informan atau informan kunci) untuk mendapat informasi yang mendalam (Indrawan, 2016: 136).

Wawancara yang dilakukan penelitian yaitu dengan mewawancarai pemimpin desa setempat dan masyarakat dewa setempat yang berada di Dusun Bondalem Desa Jumo Kecamatan Jumo Kabupaten Temanggung. Wawancara dilakukan peneliti dengan metode Tanya jawab untuk mendapatkan informasi yang lengkap dan akurat. Meskipun demikian, peneliti tidak menutup kemungkinan untuk mengajukan pertanyaan yang dapat mendukung topik penelitian.

3. Dokumentasi

Menurut Irawan (dalam Sukandarrumidi, 2004:100), studi dokumentasi merupakan teknik pengumpulan data yang ditujukan kepada subyek penelitian. Dokumen dapat berupa catatan pribadi, surat pribadi, buku harian, laporan kerja, notulen rapat, ctatan khusus, rekaman kaset, rekaman video, foto dan lain sebagainya (Sukandarrumidi, 2004: 101). Dalam teknik ini, peneliti mendapatkan informasi mengenai penerapan nilai-nilai toleransi dan sikap sosial masyarakat beda agama di Dusun Bondalem Desa Jumo Kecamatan Jumo Kabupaten Temanggung yang didapat melalui berbagai dokumetasi berupa foto kegiatan dan sumber lain yang dibutuhkan dalam penelitian ini.

Dalam peneilitian ini, penelitian menggunakan tringulasi sumber untuk mengecek keabsahan data, untuk mendapatkan data dari sumber yang berbeda-beda dengan teknik yang sama. Peneliti melakukan wawancara dengan berbagai narasumber yaitu beberapa 
warga masyarakat Dusun Bondalem, tokoh masyarakat dan Kepala Dusun Bondalem dengan teknik yang sama dan membandingkan data hasil wawancara. Penulis juga mengecek kembali hasil data wawancara yang telah didapat dengan melakukan wawancara langsung dengan orang yang bersangkutan dan benar-benar mengalami kejadian dalam permasalahan tersebut.

\section{PEMBAHASAN \\ Kondisi Geografis}

Dusun Bondalem Kabupaten Temanggung merupakansalah satu Kabupaten di Provinsi Jawa Tengah yang berbatasan dengan Kabupaten Kendal di sebelah Utara, Kabupaten Semarang di sebelah Timur, Kabupaten Magelang di sebelah Barat. Kabupaten Temanggung berjumlah penduduk sekitar 791.264 jiwa per tahun 2019. Kabupaten ini terdiri dari 20 kecamatan, salah satunya adalah Kecamatan Jumo. Kecamatan Jumo berjarak 24 $\mathrm{km}$ dari Kota Temanggung. Luas kecamatan adalah $2.932 \mathrm{ha}$, dengan rincian lahan sawah 1.654 ha. Secara administratif, Kecamatan Jumo terbagi menjadi 13 desa, 63 dusun, 269 rukun tetangga, 61 rukun warga, dengan jumlah kades 13, perangkat desa 187 dan anggota BPD 109. Dalam 63 dusun tersebut salah satunya Dusun Bondalem. Dalam satu dusun terdiri dari $90 \mathrm{KK}$ diantaranya $20 \mathrm{KK}$ beragama Budha dan $70 \mathrm{KK}$ beragama Islam. Tabel Batas Wilayah Dusun Bondalem

\begin{tabular}{|l|l|l|l|}
\hline No & \multicolumn{1}{|c|}{ Batas } & \multicolumn{1}{c|}{ Dusun/Desa } & Kecamatan \\
\hline 1. & Sebelah Utara & Dusun Godegan & Iumo \\
\hline 2. & Sebelah Selatan & Dusun Bayongan & Iumo \\
\hline 3. & Sebelah Timur & Desa Jamusan & Iumo \\
\hline 4. & Sebelah Barat & Dusun Kauman & Iumo \\
\hline
\end{tabular}

Sumber: data Desa Jumo Kecamatan Jumo

Tahun 2019/2020

\section{Kondisi sosial keagamaan masyarakat di Dusun Bondalem}

Menurut bapak Mulyono (Kepala Dusun Bondalem) menjelaskan sikap sosial keagamaan masyarakat Dusun Bondalem tergolong kategori toleran. Agama merupakan sebuah kepercayaan. Masyarakat Dusun Bondalem termasuk masyarakat plural, karena di Dusun ini terdapat dua jenis agama. Bahkan dalam seebuah rumah, ada yang memiliki kepercayaan berbeda. Adapun jenis agama yang dianut oleh masyarakat adalah agama Islam dan agama Budha. Dusun Bondalem dulunya didomisili oleh beberapa agama seperti Islam, Budha, dan Kristen. Seiring berjalannya waktu agama Islam berkembang semakin banyak. Agama Kristen menjadi kaum minoritas di Dusun tersebut karena seiring berjalannya waktu banyak pro dan kontra yang terjadi sehingga membuat umat Kristen berpindah tempat dari Dusun Bondalem. Dan sebagian masih bertahan pada agama Budha. Hal tersebut berlangsung dalam proses kehidupan masyarakat Dusun Bondalem melalui perkawinan, selain itu karena kebebasan hati nurani seseorang untuk memilih agama.

Dalam konteks ini masyarakat Dusun Bondalem hidup dengan sikap keragaman yang toleran pada semua penganut agama karena kekerabatan dalam masyarakat masih kokoh dipertahankan melalui perilaku sosial, solidaritas, dan adat istiadat dusun tersebut. Sementara agama Islam dan agama Budha memiliki persaingan yang seimbang dalam mengembangkan agamanya.

Dusun Bondalem dalam sosial keagamaan masyarakat sudah sangat toleran antara agama Islam dan agama Budha. Masyarakat Dusun Bondalem memiliki kesadaran akan perbedaan yang ada, tetapi mereka tidak mempermasalahkannya. Hal tersebut menjadi keunikan sendiri. Dalam bidang sosial masyarakat tidak pernah mengaitkan agama di dalamnya. Misalnya ada orang yang meninggal, semua warga ikut dalam membantu keluarga 
yang sedang berduka baik agama Islam maupun Budha tidak pandang latar belakang mereka. Hanya saja jika yang meninggal seorang muslim yang mengurus jenazah hanya orang muslim saja. Orang Budha membantu yang lainnya, dan mereka tidak pernah menjadikan perbedaan menjadi sebuah hambatan. Masyarakat di Dusun Bondalem menunjukkan sikap sosial pada setiap warga masyarakat dalam bentuk rasa kepedulian dan empati kepada warga yang mengalami kesusahan.

\section{Kondisi sosial masyarakat Dusun Bondalem}

Dengan latar belakang masyarakat yang berbeda tentunya hal ini membuat Dusun Bondalem memiliki banyak kegiatan yang sampai saat ini masih terus dilestarikan oleh masyarakatnya. Diantaranya beberapa kegiatan yang saat ini masih dilestarikan menurut penuturan Bapak Mulyono selaku Kepala Dusun Bondalem adalah :

1. Kegiatan kesenian Kuda Lumping

Kegiatan biasanya diadakan setiap kali ada acara-acara tertentu. Dan dilakukan dengan alunan musik gamelan disertai dengan tarian kuda lumping yang diperankan oleh remaja- remaja Dusun Bondalem tanpa membedakan latar belakang agama mereka. Semua dalam acara tersebut ikut serta di dalamnya. Bapak dan ibu ikut serta untuk membantu kelangsungan acara. Ibu-ibu membantu dengan memasak dan menyediakan makanan untuk semua warga. Bapak- bapak ikut membantu mendirikan tenda dan menyiapkan peralatan yang di butuhkan. Banyak yang datang untuk menonton kesenian ini, dari dusun- dusun lainnya. Yang ikut memeriahkan acara tersebut.

2. Agenda "TRI WULANAN"

Tri wulan adalah agenda warga Dusun Bondalem setiap 3bulan sekali untuk perkumpulan warga guna musyawarah tentang kegiatan-kegiatan yang akan dilakukan di bulan yang akan datang, dan membahas permaslahan- permasalahan yang ada di dusun untuk diselesaikan dengan baik. Selain dari kegiatan kemasyarakatan di Dusun Bondalem juga terdapat kegiatan keagamaan, antara lain:

a. Idul Fitri

Idul fitri merupakan hari raya umat Islam. Setiap umat Islam yang berada di seluruh penjuru dunia bersama-sama merayakan hari raya idul fitri. Seluruh umat Islam bersuka ria menyambut kemenangan setelah berpuasa selama satu bulan penuh. Ketika umat Islam merayakan hari raya idul fitri itu merupakan suatu hal yang lumrah, namun yang terjadi di Dusun Bondalem sangat unik dimana pada malam takbir semua umat Islam di Dusun Bondalem melakukan parade takbir keliling dengan membuat maskot-maskot yang bertema nuansa Islami.

Masyarakat juga bersilaturahmi dari rumah ke rumah. Uniknya di dusun ini, tidak hanya umat Islam saja yang bersilaturahmi, tetapi agama Budha juga ikut bersilaturahmi dari rumah ke rumah untuk meminta maaf kepada seluruh warga di Dusun Bondalem.

b. Bandulan atau Maulid Nabi

Di Dusun Bondalem acara maulid nabi dilakukan dengan bersholawat selama dua belas hari sebelum maulid nabi. Puncak dari acara maulid nabi digelar dengan cukup meriah, acaranya biasanya pengajian dengan mengundang ulama' kyai. Dalam persiapan sebelum pengaiian bukan hanya orang Islam saja yang bergotong royong untuk mendirikan panggung dan lain-lain. Akan tetapi orangorang Budha juga bersama-sama membantu persiapannya. Maulid Nabi biasanya diadakan pada malam ke-13 bulan maulid (rabi'ul awal)/ 13 bodo mulud (jawa). 
c. Waisak

Perayaan waisak di Dusun Bondalem dilakukan cukup meriah. Banyak bighu-bighu dari daerah lain ikut memeriahkan acara ini, sebelum acara tidak hanya warga Budha saja yang ikut mempersiapkan acara tersebut. Warga Islam juga ikut membantu mempersiapkan untu kelangsungan acara. Bapak-bapak ikut membantu memasang tenda dan membersihkan tempat untuk acara. Ibu-ibu juga membantu memasak dan mempersiapkan makanan. Dan selama acara berlangsung agama Islam tidak ikut dalam acara keagamaan. Hanya membantu untuk persiapan acara perayaan Hari Waisak.

\section{Kondisi ekonomi masyarakat Dusun Bondalem}

Kondisi perekonomian rata-rata masyarakat di dusun ini menengah ke bawah, kebanyakan dari warga di dusun Bondalem bekerja sebagai petani. Warga di dusun ini mendapat penghasilan uang dari hasil panen yang pada dasarnya tidak setiap hari menghasilkan uang. Seperti yang disampaikan bapak Mulyono (Kepala Dusun Bondalem) menjelaskan bahwa. Pada zaman nenek moyang warga di sana dulunya banyak yang memproduksi anyaman bambu seperti, canting dari bambu, tampah, kuda lumping dari anyaman, dll. Namun seiring berjalannya waktu semakin sedikit warga yang memproduksi anyaman. Hanya orang yang sudah tua saja yang meneruskan warisan dari nenek moyang itu, dan masih memproduksi anyaman untuk di jual ke pasaran. Itu pun tidak semua orang tua juga membuat anyaman hanya beberapa orang saja yang masih bertahan. Karena harga yang dipasarkan juga terbilang sangat murah untuk zaman sekarang ini. Kalah dengan barang-barang yang sudah modern.

\section{ANALISIS DATA \\ Penerapan Nilai-Nilai Toleransi dan Sikap Sosial Pada Masyarakat Beda Agama}

Setelah peneliti mendeskripsikan objek penelitian dengan tujuan untuk melengkapi data yang sesuai dengan lokasi penelitian, selanjutnya peneliti akan memaparkan hasil dari penelitian selama peneliti di lapangan. Penelitian ini dilakukan di Dusun Bondalem Desa Jumo, Kecamatan Jumo, Kabupaten Temanggung. Masyarakat yang berbeda agama berada dalam satu lingkungan dan menunjukkan sikap toleransi dan sikap sosial kepada setiap warga masyarakat. Dalam hal ini peneliti lebih menitik beratkan pada setiap kegiatan yang ada di masyarakat dan penerapan nilai-nilai toleransi dan sikap sosial masyarakat, berikut ini merupakan hasil penelitian selama di lapangan:

a. Kegiatan dalam bidang kesenian "Kuda Lumping"

Kesenian Kuda Lumping menjadi salah satu kegiatan yang dilakukan mayarakat setempat untuk memperingati hari-hari besar setiap tahunnya, bagi agama Islam kesenian ini dilakukan untuk memperingati Maulid Nabi Muhammad SAW, Satu Suro. Bagi agama Budha juga diperingati untuk acara-acara peresmian yang belum lama ini dilakukan untuk acara peresmian wihara yang baru resmi dibangun di dusun tersebut. Dalam acara keagamaan juga diadakan kesenian setiap kali sadranan kali, dan acara hari kemerdekaan 17 Agustus 1945 setiap tahun. Lain dari hari-hari tersebut Kuda Lumping juga diadakan setaip ada orang yang mengundang untuk memperingati hari kelahiran (ulang tahun), acara Khitanan, dll. Sebelum acara dimulai jauh-jauh hari sudah melakukan latihan setiap harinya untuk membentuk kekompakan setiap pemain. Kegiatan kesenian Kuda Lumping dilakukan semua warga dusun, khususnya remaja dusun yang beragama Islam maupun agama Budha. Tidak membedakan agama yang dianut, saling memberikan dukungan. 
b. Kegiatan perkumpulan setiap 3 bulan sekali "TRI WULANAN"

Kegiatan perkumpulan setiap warga masyarakat Dusun Bondalem dilakukan setiap 3 bulan sekali untuk membahas kegiatan-kegiatan yang akan dilakukan setaip tahunnya, dan bertujuan untuk membangun kesejahteraan masyarakat Dusun Bondalem. Kegiatan ini di kelompokkan sendiri-sendiri antara ibu-ibu dan bapak-bapak. Acara perkumpulan Dawis ibu-ibu, dan perkumpulan pengurus oleh bapak- bapak. Perkumpulan disini juga tidak membedakan antara agama Islam dan agama Budha semua campur dan ikut serta dalam perkumpulan. Sebaliknya juga untuk ibu-ibu Dawis. Sikap ini sebagai wujud toleransi dan rasa saling menghormati setiap warga Dusun Bondalem.

c. Penerapan nilai-nilai toleransi

Sikap toleransi merupakan sikap saling menghormati dan menghargai antar kelompok atau antar individu di dalam masyarakat atau yang lainnya. Toleransi di masyarakat Dusun Bondalem sangat baik, mereka menghargai antar golongan dan individu. Toleransi di Dusun Bondalem sudah ada sejak dahulu setelah Islam masuk. Sikap tersebut terus dikembangkan oleh tokoh agama Islam sehingga sampai sekarang masyarakatnya harmonis walaupun berbeda agama.

Mengembangkan sikap sosial di atas, sehingga membentuk masyarakat yang harmonis dengan cara memperkenalkan berbagai budaya yang ada dalam Islam, memperlakukan warga dengan hormat dam memberikan contoh yang baik. Dengan cara membangun kegiatan yang mempersatukan kedua agama menjadi satu dalam tujuan mempererat tali silaturahmi antar warga. Dalam peingatan Hari Besar umat muslim seperti Hari Raya Idul Fitri semua umat muslim mengadakan Sholat Ied berjamaah dan bersilaturahmi serta menjamu tamu yang datang, umat agama Budha juga ikut serta bersilaturahmi dan menyediakan makanan untuk tamu-tamu yang datang. Umat muslim pun juga bersilaturahmi dengan umat Budha sebagai wujud bertoleransi dan menghargai sesama umat manusia.

\section{Sikap Sosial Masyarakat Dusun Bondalem Desa Jumo Kecamatan Jumo Kabupaten Temanggung}

Sikap sosial yang terjalin di Dusun Bondalem Desa Jumo Kecamatan Jumo Kabupaten Temanggung diwujudkan dengan rasa kekeluargaan dan ketentraman setiap warga dusun tersebut. peneliti melihat hasil penelitian tentang sikap sosial di Dusun Bondalem ini memang cukup baik. Banyak hal kegiatan dan sikap warga masyarakat sendiri yang mencerminkan kehidupan yang nyaman antar sesama warga. Warga saling bertegur sapa jika berpapasan dijalan atau bertemu di depan rumah, saling bercengkerama layaknya keluarga. Jika ada warga yang sedang sakit, masyarakat yang lain juga menjenguknya, dan dalam kegiatan-kegiatan di masyarakat semua warga ikut serta di dalamnya baik yang beragama Islam maupun agama Budha.

Faktor Pendorong dan Penghambat Penerapan Nilai-Nilai Toleransi dan Sikap Sosial Pada Masyarakat Beda Agama di Dusun Bondalem Desa Jumo Kecamatan Jumo Kabupaten Temanggung

Kehidupan yang tentram dan aman, lingkungan yang nyaman, serta kesejahteraan adalah faktor yang mendorong warga masyarakat Dusun Bondalem untuk selalu berbuat baik dan menghormati sesama warga di dusun ini. Semua hal dan kegiatan yang ada di masyarakat dilakukan dengan landasan kehidupan yang damai. Tidak membedakan agama yang dianutnya walaupun berbeda. Semua warga saling memberikan kesempatan dan waktu untuk beribadah.

Faktor penghambat untuk warga masyarakat Dusun Bondalem sendiri berdasarkan pengakuan dari ibu Sugiyanti, yaitu adanya sikap warga yang terlalu fanatik terhadap 
agamanya sendiri, hal ini menjadi pemicu permasalahan kecil dalam masyarakat terutama warga masyarakat Dusun Bondalem ini. Adanya warga yang seperti ini menjadikan warga yang lain kurang nyaman dan bisa menjadi penghambat warga untuk berbaur satu dengan yang lainnya dan menjalankan kegiatan- kegiatan warga juga pasti akan canggung dan kurang nyaman.

\section{SIMPULAN}

Berdasarkan paparan data dan analisis data, maka dapat disimpulkan beberapa hal mengenai penerapan nilai-nilai toleransi, sikap sosial masyarakat beda agama, faktor penghambat dalam masyarakat beda agama, berdasarkan focus masalah sebagai berikut:

1. Penerapan nilai-nilai toleransi antar umat beda agama, dalam mengembangkan sikap toleransi adalah dimulai dari sikap diri senidiri yang menghargai dan menghormati setiap manusia. Penerapan nilai-nilai toleransi yang ada di Dusun Bondalem terjaga dengan baik, rasa toleransi sesama warga masyarakat juga terlihat dalam sikap menghormati setiap warga satu dengan yang lain. Walaupun berbeda agama tetapi saling menghormati satu dengan yang lain dalam hal ibadah maupaun sosial. Seperti tidak mengganggu orang yang sedang beribadah, dan jika ada orang yang sakit warga juga ikut menjenguk dan mendoakan. Nilai toleransi yang ada di masyarakat Dusun Bondalem sangat baik. Hal ini dapat dijadikan motivasi agar kita lebih memehami orang lain dan lebih bertoleransi dengan sesama orang disekitar kita.

2. Sikap sosial yang ada di Dusun Bondalem, terwujud dari sikap setiap warga masyarakat yang bergotong royong dalam setiap kegiatan yang diadakan, tanpa memandang agama, keyakinan, dan derajat setiap orang. Dalam kegiatan-kegiatan di Dusun Bondalem seperti kesenian "Kuda Lumping", perkumpulan bapak-bapak dan ibu-ibu setiap 3 bulan sekali (Tri Wulanan) semua warga bahu membahu ikut serta dalam kegiatan tersebut. jika yang ada warga yang meninggal di dusun ini semua warga juga antusias ikut membantu keluarga yang sedang berduka, Sikap ini sebagai bentuk sikap sosial masyarakat di Dusun Bondalem yang terjalin dengan baik.

3. Kehidupan yang tentram dan aman, lingkungan yang nyaman, serta kesejahteraan adalah faktor yang mendorong warga masyarakat Dusun Bondalem untuk selalu berbuat baik dan menghormati sesame warga masyarakat. Faktor penghambat untuk warga masyarakat Dusun Bondalem sendiri yaitu adanya sikap warga yang terlalu fanatik terhadap agamanya sendiri, hal ini menjadi pemicu permasalahan kecil dalam masyarakat terutama warga masyarakat Dusun Bondalem

\section{DAFTAR PUSTAKA}

Abdussami, Humaidy, dan Masnun Tahir. 2003. Islam dan Hubungan Antar Agama (Wawasan untuk Para Da'i). Yogyakarta: LKiS.

Basrowi dan Suwandi. 2008. Memahami Penelitian Kualitatif. Jakarta: Rineka Cipta. Indrawan, Rully dan R. Roppy yaniawati. 2016. Metodologi Penelitian Kuantitatif, Kualitatif, dan Campuran untuk Manajemen, Pembangunan, dan Pendidikan (Revisi). Bandung: PT. Refika Aditama.

Miswari, Zuhairi. 2007. Al-Qur'an Kitab Toleransi. Jakarta: Pustaka Oasis.

Moleong, Lexy J. 2008. Metodologi PenelitianKualitatif. Bandung: PT Remaja Rosdakarya

Naim, Ngainun. 2008. Pendidikan Multikultural: Konsep dan Aplikasi. Yogyakarta: Arruzz Media. 
Rahmat, M. Imammudin. 2003. Islam Pribumi Mendialogkan Agama,Membaca Realita. Jakarta: Erlangga.

Sukandarrumidi. 2004. Metodologi Penelitian: Petinjuk Praktis untuk Peneliti Pemula. Yogyakarta: Gadjah Mada University Press.

Yewangoe, A.A. 2009. Agama dan Kerukunan. Jakarta: Gunung Mulia. 